Kirwin R. Shaffer, Anarchists of the Caribbean: Countercultural Politics and Transnational Networks in the Age of US Expansion. Cambridge: Cambridge University Press, 2020. xiv + 318 pp. (Cloth US\$99.99)

There are books that present an idea developed over many years in which each page demonstrates the depth of their authors' knowledge on the topics covered. That is the case of Anarchists of the Caribbean. In past years, Kirwin R. Shaffer has become a leading figure in the study of Caribbean anarchism, producing major works on Cuba, Puerto Rico, and Latin America in general. His new book is the product of decades of meticulous archival research, showcasing his vast knowledge on the histories of anarchism in the Caribbean Basin.

Anarchists of the Caribbean continues Shaffer's interest in anarchism's regional yet transnational histories. It offers an overview of how anarchists built a well-organized radical network that operated in different countries. While the book focuses on Panama, Cuba, Puerto Rico, and Florida, it also sheds light on anarchist organizing in Mexico, New York, and Central America. Shaffer is also a prolific storyteller. The book is organized thematically and follows a chronological line from the 189 os to the 1930s. Each chapter successfully weaves together succinct narratives documenting complex processes and networks of individuals.

Chapter 1 explores the important role that anarchists played in Cuba's War for Independence (1895-98). After the war, the United States expanded its imperial reach in the region through a series of military and economic interventions. Anarchists did not stand by passively but, as Chapter 2 demonstrates, they organized a regional network to resist U.S. neocolonialism. This network came alive through print media, solidarity campaigns, and the circulation of radical individuals. In Chapters 3 and 4 , Shaffer looks at the ways that anarchists in the Caribbean Basin used those networks to actively participate in international events, such as the Mexican Revolution, the U.S. Red Scare, and the Russian Revolution.

Attentive to the continuity of U.S. interventions in the region, Chapter 5 explores how Caribbean anarchists demanded labor rights in the Panama Canal, reacted to World War I, and critiqued U.S. colonialism in Puerto Rico. Provocatively, Shaffer argues that "Caribbean anarchists were the Latin American anti-imperialist left years - and even decades - before Caribbean Marxists took marching orders from Moscow to form anti-imperialist leagues" (p. 213). In the last two chapters, Shaffer argues that anarchists developed what he calls bolivarianismo anarquista (anarchist bolivarianism), a Pan-American vision that sought to ideologically unite anarchists across the region. However, this was truncated by the repression that anarchists faced not only from state offi- 
cials but also by the decreasing influence over labor organizations after the proliferation of Communism in the region.

The book makes several crucial interventions in the scholarship on Caribbean radicalisms. First, it demonstrates the materiality of the transnational connections that anarchists created. Through these vibrant networks, workers mobilized funds to support international revolutions, articulated relentless critiques of U.S. imperialism, and served as cartographies of safe spaces for migrants traveling from one country to another. Second, as the title of the book suggests, Shaffer not only pays attention to anarchism but also to the ways U.S. imperialism impacted the region and the ways anarchists responded to it. This is particularly important because of anarchism's internationalist ethos. While they opposed nation states, Shaffer complicates this by looking at the intersections of early-twentieth-century anarchist organizing with national liberation struggles and other political ideologies at the turn of the twentieth century.

Lastly, the book unearths and connects a vibrant archive of radical print media and cultural production that ties the narrative together. Anarchists were inexhaustible writers. Wherever there were a handful of anarchists, there was a newspaper. And wherever there was a newspaper, there were international exchanges. Some papers only lasted for a few issues but others, like Havana's ¡Tierra! survived for many years. Shaffer has been able to piece together the plethora of print media produced by anarchists at the turn of the twentieth century to write a rich history with many moving pieces, individuals, and events. The archive he has built for this book is the product of an intellectual endeavor that took him many years to craft. This titanic task has enriched the book's narrative and makes it compulsory reading for anyone interested in the Hispanic Caribbean at the turn of the twentieth century.

\section{Jorell Meléndez-Badillo}

Department of History, Dartmouth College, Hanover NH, U.S.A. jorell.a.melendez-badillo@dartmouth.edu 